\title{
Biological activity of wild Ligularia fischeri leaf extracts in the development of functional food materials
}

\author{
Su-Bin Lim ${ }^{1}$, Myung-Uk Kim², Kyeung-Il Park ${ }^{3}$, Eun-Ho Lee ${ }^{1}$, Ye-Jin Kim ${ }^{1}$, \\ Eun-Bi Cho', Byeong-Oh Kim ${ }^{1}$, Young-Je Cho ${ }^{1 *}$ \\ ${ }^{1}$ School of Food science and Biotechnology/Food and Bio-industry Research Institute, Kyungpook National University, \\ Daegu 41566, Korea \\ ${ }^{2}$ Gyeongbuk Institute for Marin Bio-industry, Uijin 36315, Korea \\ ${ }^{3}$ Department of Horiticulture and Life Science, Yeungnam University, Gyeongsan 38541, Korea
}

\section{기능성 식품소재 개발을 위한 야생 곰취잎 추출물의 생리활성}

\author{
임수빈 ${ }^{1} \cdot$ 김명 욱 ${ }^{2} \cdot$ 박경일 $^{3} \cdot$ 이은호 ${ }^{1} \cdot$ 김예진 $^{1} \cdot$ 조은비 ${ }^{1} \cdot{\text { 김병 } \text { 오 }^{1} \cdot \text { 조영제 }}^{1 *}$ \\ 1경북대학교 식품공학부/식품생물산업연구소, ${ }^{2}$ 경북해양바이오산업연구원, ${ }^{3}$ 영남대학교 원예생명과학과
}

\begin{abstract}
The objective of this study was to identify the anti-oxidation, astringent, and inhibition effects of wild Ligularia fischeri on hyaluronidase and angiotensin conerting enzyme (ACE). In order to identify the total phenolic compound (TPC), various solvents were used for extraction showing hot water extract with the highest value of 14.42 GAE $\mathbf{m g} / \mathrm{g}$. In addition, ABTS radical scavenging activity measurements revealed an anti-oxdiation effect of $\mathbf{9 8 . 6 4 - 9 9 . 8 4 \%}$ a hot water extract concentration of $50-200 \mu \mathrm{g} / \mathrm{mL}$ and a radical scavenging activity of $95.14-98.96 \%$ at a $60 \%$ ethanol extract content. If expressed in antioxidant protection factors (PF), the hot water extract showed 0.59-1.02 $\mathrm{PF}$ and the $60 \%$ ethanol sample displayed 0.30-0.74 PF. To identify the bio-activity effect, the hyaluronidase inhibition effect was determined as $4.66-35.00 \%$ in a 50-200 $\mathrm{\mu g} / \mathrm{mL}$ hot water extract. Considering ACE inhibition effect, the hot water extract and $60 \%$ ethanol sample showed $0-64.24 \%$ and $46.12-69.64 \%$ inhibition effect, respectively. Lastly, when taking into account the astringent effect, the hot water extract with 50-200 $\mathrm{\mu g} / \mathrm{mL}$ TPC concentration showed $15.68-26.92 \%$ and the $60 \%$ ethanol sample with an equal concentration exhibited $49.48-86.84 \%$, which indicates the possibility to apply this product as a cosmetic source for pore contraction. Therefore, wild Ligularia fischeri extract can be used for anti-inflammation, high-blood pressure prevention, and as a source for health functional food with anti-oxidative properties.
\end{abstract}

Key words : wild Ligularia fischeri, extracts, ant-oxidant, anti-inflammation, anti-hypertension

\section{서 론}

취나물은 우리나라 산야에 자생하는 식물로서 쓴맛을 내는 특징을 가지고 있으며 매우 다양한 종류가 자생하고

*Corresponding author. E-mail : yjcho@knu.ac.kr Phone : 82-53-950-7755, Fax : 82-53-950-7762

Received 25 April 2018; Revised 21 May 2018; Accepted 24 May 2018.

Copyright (c) The Korean Society of Food Preservation. All rights reserved.
있다. 식용가능한 취나물은 곰취, 개미취, 미역취, 수리취, 참취, 청옥취, 누룩취 등이 있다. 그중에서도 곰취(Ligularia fischeri)는 전국의 습윤하고 비옥한 산림지대 어디에서나 자생하는 다년생 초본으로 연한 잎을 나물 및 쌈으로 식용 한다(1). 곰취는 비타민 $\mathrm{A}, \mathrm{B}_{1}, \mathrm{~B}_{2}, \mathrm{C}, \beta$-carotene과 niacin 등이 고루 함유되어 있는데 이중 비타민A와 그 전구체인 $\beta$-carotene의 함량이 다른 채소류에 비하여 높은 함량을 보이고 있다. 민간에서는 가래와 고름을 제거하고 기침을 멎게하는 용도로 사용하고 있으며 $(2,3)$ 현재까지 진행된 연구로는 MMP-1 발현 저해효과(4), 간암세포에 대한 세포 
독성(5), 곰취의 기능성 소재화를 위한 추출조건 설정(6) 등이 있다.

생리활성물질은 동식물에 다양하게 분포하는 물질로 생 리활성효과를 가지는 물질들을 총칭한다. 생리활성효과란 생명활동에 필요한 물질의 결핍이나 과도한 분비에 의한 비정상적인 상태를 완화하고 병태의 치료에 도움을 주는 효과이다. 일반적으로 생리활성효과는 생리활성물질의 농 도에 비례하여 그 효능 혹은 효과가 증가하기 때문에 최근 소비자들은 식품으로 섭취하는 생리활성물질 이외에도 약 품 혹은 보충제 등을 통하여 생리활성물질을 추가로 섭취하 고 있다. 생리활성물질에는 대표적으로 flavonoids, polyphenol 과 같은 물질이 존재하며, 고혈압 예방에 도움, 항산화, 염증 을 완화, 피부 주름 개선에 도움을 주는 등의 물질들이 많다. 전 세계의 모든 동식물에 존재하기 때문에 현재까지 연구된 물질이 굉장히 많음에도 불구하고 아직도 다양한 분야에서 연구가 진행 중이다(7).

본 연구는 우리나라에서 흔히 먹는 야생 곰취의 생리활 성효과를 탐색하고 이를 통하여 건강기능성식품의 원료로 개발하기 위한 기초 자료로 제공하고자 한다.

\section{재료 및 방법}

\section{야생 곰취 분말 및 추출물 제조}

본 연구에 사용된 곰취 잎은 대구 팔공산 인근의 야산에 서 자생하고 있는 상태의 야생 곰취 잎을 채취한 후 $50^{\circ} \mathrm{C}$ dry oven(FO-600M, Jeiotech, Daejeon, Korea)에서 건조하여 $40 \mathrm{mesh}$ 로 분쇄하였으며, 분말은 $4^{\circ} \mathrm{C}$ 에서 저온 저장하며 시료로 사용하였다. 추출물 제조는 열수 추출물의 경우 곰 취 분말 $1 \mathrm{~g}$ 에 증류수 $200 \mathrm{~mL}$ 를 가하고 가열교반기를 사용 하여 약 1 시간정도 $100 \mathrm{~mL}$ 가 될 때까지 가열하여 끓인 후 $4^{\circ} \mathrm{C}$ 에서 $120 \mathrm{rpm}$ 으로 24 시간 동안 교반 추출하였다. Ethanol 추출물은 곰취 분말 $1 \mathrm{~g}$ 에 $100 \mathrm{~mL}$ 의 $60 \%$ ethanol을 추출용매로 가하여 에탄올이 증발하지 않게 마게를 덮어 밀봉한 후 24 시간 동안 $4^{\circ} \mathrm{C}$ 에서 $120 \mathrm{mpm}$ 으로 교반 추출하였 다. 추출액은 Whatman No.1 filter paper(Whatman Inc., Piscataway, NJ, USA)로 여과한 후 ethanol을 제거하기 위하 여 rotary vacuum evaporator(Buchi Co., Uster, Switzerland) 으로 농축하여 시료로 사용하였다.

\section{Total polyphenol 화합물 정량 및 농도조절}

Total polyphenol 화합물 정량은 Folin과 Denis의 방법(8) 에 준하여 측정하였으며, 시료 $1 \mathrm{~mL}$ 에 $95 \%$ ethanol $1 \mathrm{~mL}$ 와 증류수 $5 \mathrm{~mL}$ 를 첨가하고 $1 \mathrm{~N}$ Folin-ciocalteu reagent(Junsei, Tokyo, Japan) $0.5 \mathrm{~mL}$ 를 섞어 $\mathrm{Na}_{2} \mathrm{CO}_{3} 1 \mathrm{~mL}$ 를 가하여 1시간 동안 암실에 방치한 후, UV-visible spectrophotometer (Optizen 3220UV, Mecasys Co., Daejeon, Korea)을 이용하
여 $725 \mathrm{~nm}$ 의 파장으로 흡광도를 측정하여 gallic acid를 이용한 표준곡선으로부터 양을 환산하였다.

각 추출물의 생리활성의 측정은 생리활성 물질로 알려져 있는 phenolic 농도를 측정한 후 농축 및 희석 과정을 통하여 phenolic 농도를 50-200 $\mathrm{\mu g} / \mathrm{ml}$ 로 농도구간은 4구간으로 조 절하여 실험하였다.

\section{항산화 효과 측정}

2,2'-Azinobis-(3-ethylbenzothiazoline-6-sulfonic acid) radical cation decolorization(ABTS)의 측정은 Fellegrin 등의 방법 (9)에 준하여 측정하였고, 저해율(\%)은 1-(반응구의 흡광도 /대조구의 흡광도) $\times 100$ 으로 나타내었다. Antioxidant protection factors $(\mathrm{PF})$ 는 Andarwulan과 Shetty의 방법(10)에 준하여 측 정하였으며, $\mathrm{PF}$ 는 (반응구의 흡광도/대조구의 흡광도)의 비로 나타내었다.

\section{Hyaluronidase 저해 효과 측정}

Hyaluronidase(HAase) 저해활성은 Dorfman과 Ott의 방 법(11)에 준하여 측정하였다. 반응구는 시료 $0.5 \mathrm{~mL}$ 에 20 $\mathrm{mM}$ Sodium phosphate buffer(pH 6.9)에 녹인 HAase(1,000 $\mathrm{U} / \mathrm{mL}) 0.5 \mathrm{~mL}$ 을 혼합하여 $38^{\circ} \mathrm{C}$ 에서 5 분간 반응시키고 0.3 $\mathrm{M}$ phosphate buffer(pH 5.3)에 녹인 기질 $(4 \mathrm{mg} / \mathrm{mL}) 0.5 \mathrm{~mL}$ 을 넣어 다시 $38^{\circ} \mathrm{C}$ 에서 45 분간 반응시킨 후 $0.04 \mathrm{M}$ acetate buffer(pH 3.75)에 녹인 알부민용액 $5 \mathrm{~mL}$ 을 첨가한 후 5 분간 방치하고 $600 \mathrm{~nm}$ 에서 투과율을 측정하였다. 대조구는 시료 대신 증류수 $0.5 \mathrm{~mL}$ 를 넣어 반응시켰으며, 저해율(\%)은 (1-반응구의 투과율/대조구의 투과율) $\times 100$ 으로 계산하였 다.

\section{Angiotensin converting enzyme(ACE) 저해 효과 측정}

$\mathrm{ACE}$ 저해효과 측정은 Cushman과 Cheung의 방법(12)에 준하여 측정하였다. 즉, 반응구는 $0.3 \mathrm{M} \mathrm{NaCl}$ 을 함유하는 $0.1 \mathrm{M}$ potassium phosphate buffer(pH 8.3)에 기질인 hippuryl-L-histidyl-Leucine(HHL, Sigma-Aldrich Co., Louis, $\mathrm{MO}, \mathrm{USA}) 2.5 \mathrm{mM}$ 을 녹인 액 $0.15 \mathrm{~mL}, \mathrm{ACE}(0.25 \mathrm{unit} / \mathrm{mL}$, Sigma-Aldrich Co.) $0.1 \mathrm{~mL}$ 와 각 시료 용액 $0.1 \mathrm{~mL}$ 를 혼합하 였으며, 대조구는 시료 대신 증류수 $0.1 \mathrm{~mL}$ 를 첨가하여 $37^{\circ} \mathrm{C}$ 에서 30 분간 반응시키고, $1 \mathrm{~N} \mathrm{HCl} 0.25 \mathrm{~mL}$ 첨가로 반응을 중지시킨 뒤 $3 \mathrm{~mL}$ 의 ethylacetate를 첨가하였다. Ethylacetate 층으로부터 용매를 증류시킨 잔사에 $2 \mathrm{~mL}$ 의 증류수를 첨가하여 추출된 hippuric acid를 spectrophotometer (Optizen 3220UV, Mecasys Co.)를 사용하여 $280 \mathrm{~nm}$ 파장에 서 흡광도를 측정한 후 hippuric acid 표준곡선으로부터 생 성량을 환산하였다. 저해율(\%)은 (1-반응구의 hippuric acid 생성량/대조구의 hippuric acid 생성량) $\times 100$ 으로 계산하 였다. 


\section{Astringent 효과 측정}

Astringent 효과 측정은 Lee 등의 방법(13)에 준하여 측정 하였다. 0.2 M sodium phosphate buffer(pH 7.5) $100 \mathrm{~mL}$ 에 hemoglobin $5 \mathrm{~g}$ 을 첨가하여 $5 \%$ hemoglobin 용액을 제조하 였다. 반응구는 $5 \%$ hemoglobin 용액 $1 \mathrm{~mL}$ 와 시료 $1 \mathrm{~mL}$, buffer $1 \mathrm{~mL}$ 를 혼합하여 VS-6000N 원심분리기(VISION SCIENTIFIC, Daejeon, Korea)를 이용하여 2,000 rpm으로 30 분간 원심분리하였으며, 대조구는 시료 대신 증류수 1 $\mathrm{mL}$ 를 첨가하여 원심분리하였다. 그 후 상등액 $2 \mathrm{~mL}$ 를 취하 여 spectrophotometer(Optizen 3220UV, Mecasys Co.)를 사 용하여 $576 \mathrm{~nm}$ 파장에서 흡광도를 측정하여 침전율을 계산 하였다. 침전율 $(\%)$ 은 (1-반응구의 흡광도/대조구의 흡광 도) $\times 100$ 으로 계산하였다.

\section{통계처리}

모든 실험은 3회 이상 반복 측정하였고 자료의 통계처리 는 IBM SPSS statistics ver. 22 for windows(SPSS Inc., Chicago, IL, USA)를 이용하여 평균 \pm 표준편차(mean $\pm \mathrm{SD}$ ) 로 표시하였고 분산분석(ANOVA)과 Duncan's multiple range test를 실시하여 시료간의 유의차를 $\mathrm{p}<0.05$ 수준으로 비교 분석하였다.

\section{결과 및 고찰}

야생 곰취 추출물의 total polyphenol compounds 함량 측정

Total polyphenol compounds(TPC)는 식물체의 2 차 대사 산물로서 다양한 식물군에서 약 8,000 개의 물질이 분리 정 제되어 그 구조가 밝혀져 있다. 식물체는 phenylpropanoid pathway를 통해 생성된 물질들을 이용하여 여러 가지 유도 체들을 생성하게 된다. 일반적으로 $\mathrm{TPC}$ 는 식물들이 자외선 으로부터 방어, 병원체에 대한 면역 등을 위하여 생성하는

(A)

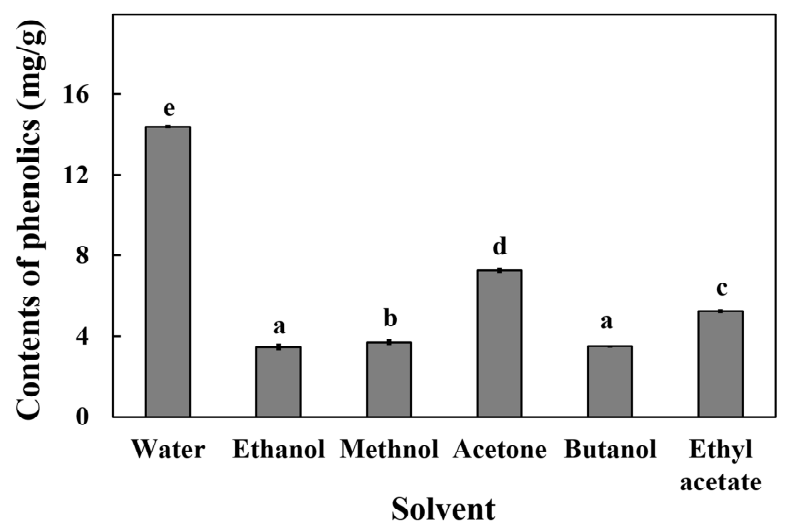

물질이지만 최근의 연구에 의하면 인체 내에서 항산화, 암 세포 생장 억제, 심혈관계 질환 완화 등 다양한 생리활성 효과를 가지는 것으로 보고되었다 $(14,15)$. 본 연구에서는 이러한 생리활성 효과를 가지는 $\mathrm{TPC}$ 를 추출하는 최적조건 을 찾아보고자 하였다. TPC의 양은 gallic acid를 이용한 표준곡선으로부터 환산하였다. 다양한 용매를 이용하여 추 출한 결과 Fig. $1 \mathrm{~A}$ 에서와 같이 열수 추출물에서 $14.42 \mathrm{GAE}$ $\mathrm{mg} / \mathrm{g}$ 으로 가장 높은 추출 수율을 나타내었고 acetone, ethyl acetate, methanol, butanol, ethanol 순으로 추출 수율이 감소 하는 양상을 나타내었다. 곰취 추출물을 식품 소재로 사용 하기 위하여 인간에게 해가 없는 것으로 알려진 물과 ethanol을 추출 용매로 선택하였고, 추출 시간에 따른 추출 수율을 알아보기 위하여 3시간 간격으로 추출한 결과 Fig. $1 \mathrm{~B}$ 에서와 같이 열수 추출물은 추출 시간이 증가함에 따라 추출수율이 증가하는 결과를 나타내었으며 ethanol 추출물 은 시간에 따른 유의적 차이는 나타나지 않았다.

\section{야생 곰취 추출물의 항산화 효과}

$\mathrm{ABTS}$ 와 potassium persulfate가 16 시간 이상 반응하여 생성된 ABTS+ free radical은 짙은 청록색을 나타내지만 항산화 물질과 만나면 무색으로 탈색되는 성질을 가지고 있다. ABTS 라디칼 소거능은 이러한 원리를 이용하여 항산 화 효과를 측정할 수 있는 방법으로, 가장 널리 사용되는 항산화 효과 측정 방법 중 하나이다(16). 곰취 추출물의 $\mathrm{ABTS}$ 라디칼 소거능을 측정한 결과 $\mathrm{Fig} 2 \mathrm{~A}$ 에서와 같이 열수추출물은 50-200 $\mathrm{\mu g} / \mathrm{mL}$ 의 TPC 농도에서 98.64-99.84\% 의 라디칼 소거능을 나타내었고, $60 \%$ ethanol 추출물은 95.14-98.96\%의 라디칼 소거능을 나타내었다. positive control로 사용한 BHT는 $50-200 \mu \mathrm{g} / \mathrm{mL}$ 의 농도에서 $30.33-84.9 \%$ 로 곰취 추출물보다 낮은 라디칼 소거능을 나 타내었다. Song 등(17)은 조릿대 열수, 에탄올 추출물이 각 각 $500 \mu \mathrm{g} / \mathrm{mL}$ 농도에서 $60.89 \%, 61.77 \%$ 의 ABTS 라디칼

(B)

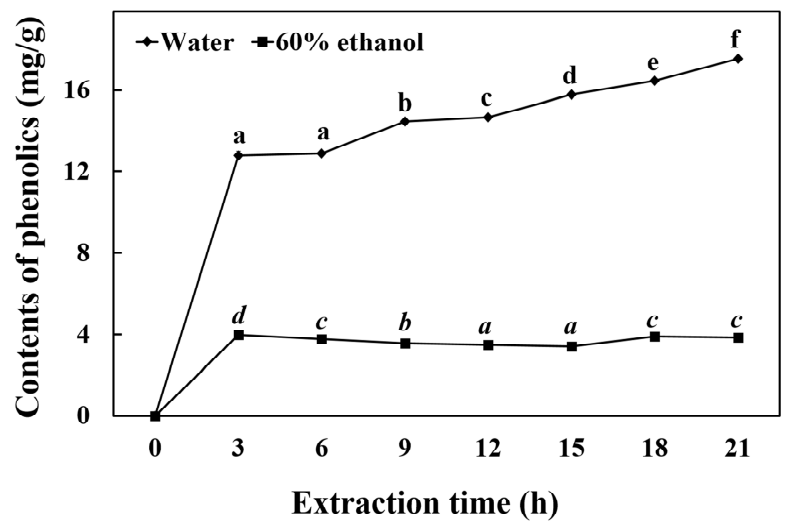

Fig. 1. Content of phenolics in various solvents (A) and extraction time (B) of water and $60 \%$ ethanol extracts from wild Ligularia fischeri. Values with different alphabet in the column were significantly different among group at $\mathrm{p}<0.05$ level by Duncan's multiple range test. 
소거능을 나타내었다고 보고한 결과와 비교하였을 때, 곰 취의 $\mathrm{ABTS}$ 라디칼 소거능이 더 우수하다고 판단되었다.

$\mathrm{PF}$ 는 $\beta$-carotene linoleate system을 이용한 항산화 효과 측정방법이다. $\beta$-Carotene linoleate system은 불포화 지방산 의 산패 과정에서 생성된 free radical이 $\beta$-carotene을 산화시 켜 $\beta$-carotene의 특유의 색을 탈색시키게 되는데, 이 과정에 서 산화된 $\beta$-carotene은 free radical의 연쇄 산화반응을 중단 시켜 free radical의 반응성을 잃게 만든다. $\mathrm{PF}$ 는 이러한 원리 를 이용하여 지용성 물질의 항산화 효과를 측정하는데 널리 사용된다(18). 곰취 추출물의 $\mathrm{PF}$ 를 측정한 결과, Fig. $2 \mathrm{~B}$ 에 서와 같이 열수추출물은 $50-200 \mu \mathrm{gg} / \mathrm{mL}$ 의 TPC 농도에서 0.59-1.02 PF를 나타내었고, $60 \%$ ethanol 추출물에서는 0.30-0.74 PF를 나타내었다. 열수 추출물의 경우 50-200 $\mu$ $\mathrm{g} / \mathrm{mL}$ 의 농도에서 농도가 증가함에 따라 $\mathrm{PF}$ 가 유의적으로

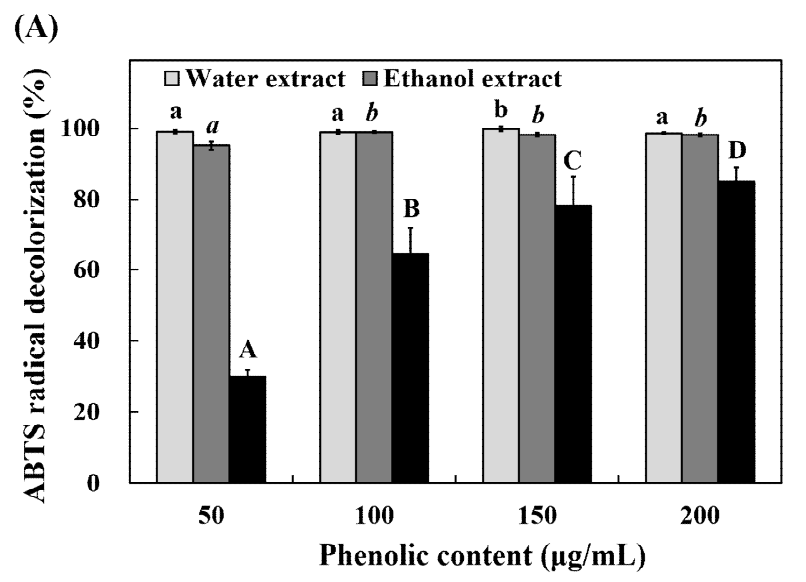

증가하였으나, $60 \%$ ethanol 추출물의 경우 농도가 증가함에 따라 PF가 유의적으로 감소하는 결과를 나타내었다. 이는 $60 \%$ ethanol 추출물이 지용성 물질에 대한 항산화 효과를 나타내지 못하며, TPC의 농도가 높아짐에 따라 sample의 색 또한 진하게 나타나 발생한 결과로 판단되었다. Positive control로 사용한 BHT는 같은 농도에서 1.01-1.16 PF를 나 타내었다.

\section{야생 곰취 추출물의 hyaluronidase 저해효과}

Hyaluronic acid(HA)는 세포 외 기질(extracellular matrix, $\mathrm{ECM}$ 을 이루는 거대분자로, 세포 내부와 혈관, 폐 등에도 존재한다. 일반적으로 고분자의 $\mathrm{HA}$ 는 염증을 예방하며 상 처 치유와 혈관신생, 세포 분화에 관여 한다고 알려져 있으 나, hyaluronidase(HAase)등에 의하여 저분자로 분해된 $\mathrm{HA}$

Fig. 2. ABTS cation radical decolorization (A) and antioxidant protection factor (B) as anti-oxidative activities of water and $60 \%$ ethanol extract from wild Ligularia fischeri.

Values with different alphabet in the column were significantly different among group at $\mathrm{p}<0.05$ level by Duncan's multiple range test.

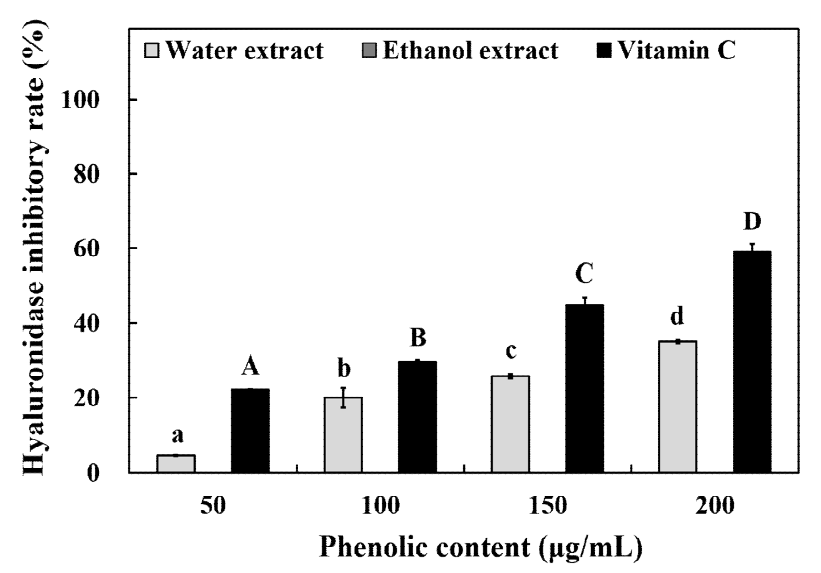

Fig. 3. Inhibitory activity against hyaluronidase of water and $60 \%$ ethanol extract from wild Ligularia fischeri.

Values with different alphabet in the column were significantly different among group at $\mathrm{p}<0.05$ level by Duncan's multiple range test.
(B)

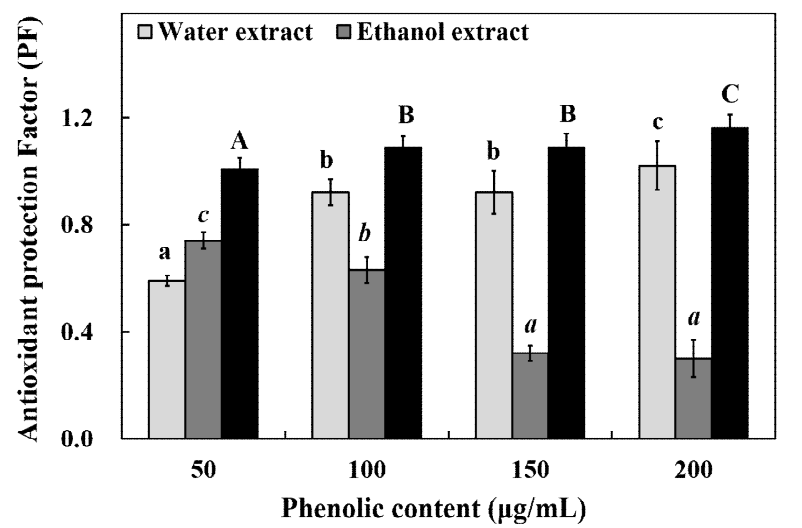




\section{야생 곰취 추출물의 $\mathrm{ACE}$ 저해효과}

인체 내의 혈압조절 시스템중 하나인 RAAS(Reninangiotensin-alodosterone system)는 체액내의 물질들을 이용 한 혈압조절 시스템이다. 동맥 내의 혈류량이 감소하여 혈 압이 감소하면 신장의 사구체에서 레닌(renin)이 분비된다. 레닌은 혈장내의 angiotensiogen을 활성화시켜 angiotensin $\mathrm{I}$ 로 전환시키고, angiotensin I은 angiotensin converting enzyme의 작용을 받아 angiotensin 포 전환된다. Angiotensin П는 angiotensin $\Pi$ type 1 수용체(AT1)와 결합하여 부신피 질을 자극시키고 알도스테론(aldosterone)의 분비를 촉진한 다. 분비된 알도스테론은 신장에서 나트륨 이온의 재흡수 를 촉진하여 결과적으로 혈압을 상승시킨다 $(22,23)$. 이 과 정에서 중요한 역할을 하는 것이 $\mathrm{ACE}$ 로, $\mathrm{ACE}$ 의 활성을 저해하는 것을 통하여 급격한 혈압 상승을 억제할 수 있다. 곰취 추출물의 $\mathrm{ACE}$ 저해 효과를 측정한 결과 Fig. 4 에서와 같이 열수 추출물은 $50-200 \mu \mathrm{gg} / \mathrm{mL}$ 의 TPC 농도에서 $0-64.24 \%$ 의 ACE 저해 효과를 나타내었으며, $60 \%$ ethanol 추출물의 경우 46.12-69.64\%의 $\mathrm{ACE}$ 저해 효과를 나타내었 다. Positive control로 사용한 captopril은 $50-200 \mu \mathrm{g} / \mathrm{mL}$ 의 농도에서 $40.32-70.96 \%$ 로 $150 \mathrm{\mu g} / \mathrm{mL}$ 의 농도까지는 곰취 $60 \%$ ethanol 추출물 보다 낮은 $\mathrm{ACE}$ 저해 효과를 나타내었 고 $200 \mu \mathrm{g} / \mathrm{mL}$ 의 농도에서는 비슷한 저해 효과를 나타내었 다. Kwon과 Youn은(24)이 모링가를 1:10의 비율로 추출한 물 추출물과 ethanol 추출물이 각각 $34.81 \%$ 와 $27.68 \%$ 의 $\mathrm{ACE}$ 저해 효과를 나타낸다고 보고한 결과와 비교하였을 때, 야생 곰취 추출물의 $\mathrm{ACE}$ 저해 효과가 더 우수하다고 판단되었다. 또, 현재는 사용량이 줄었으나, 실제로 고혈압 환자에게 사용하는 약물인 captopril과 비교하였을 때, 곰취 추출물의 $\mathrm{ACE}$ 저해 효과의 우수성이 충분히 입증되어 향 후 고혈압 예방 및 치료를 위한 식품소재로서 활용이 가능 할 것이라 판단되었다.

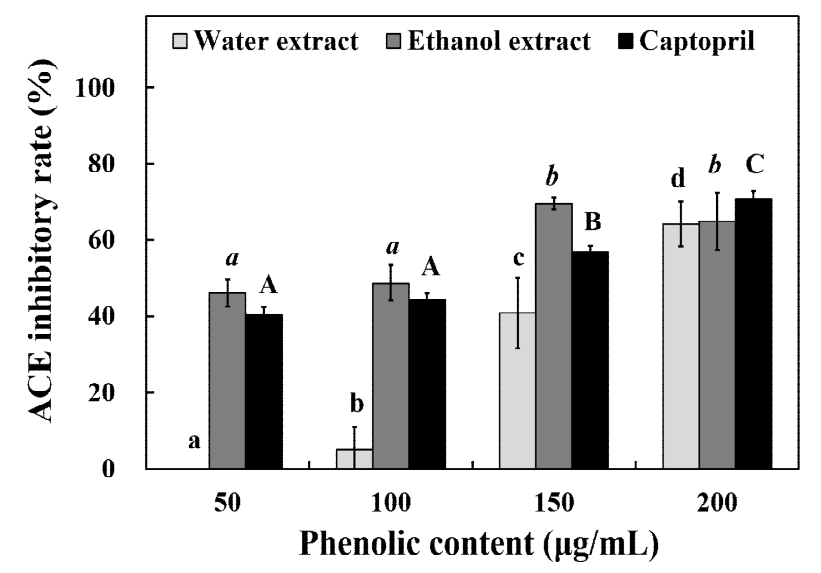

Fig. 4. Inhibitory activity against angiotensin converting enzyme of water and $60 \%$ ethanol extract from wild Ligularia fischeri.

Values with different alphabet in the column were significantly different among group at $p<0.05$ level by Duncan's multiple range test.

\section{야생 곰취 추출물의 atringent 효과}

Astringent는 '수렴'의 의미를 포함하고 있는 단어로 '한 곳으로 모이는', '뭉치는'이라는 뜻을 가지고 있다. Astringent의 원리는 식물체 내에 존재하는 polyphenol compounds와 flavonoids가 단백질과 같은 거대분자에 작용 하여 서로 뭉치거나 가교결합을 형성하게 만든다. 이러한 원리를 피부에 적용시키면 식물체에 포함되어있는 polyphenol compounds와 flavonoids가 모공 주변의 단백질들 사이에 가교결합을 형성하도록 하여 모공을 수축하는 효과를 기대 할 수 있다(25). 직접적으로 동물실험이 불가능했기 때문에 시험관 내에서 hemoglobin을 이용하여 추출물의 astringent 를 간접적으로 확인할 수 있었다. 곰취 추출물의 astringent 효과를 측정해본 결과 Fig. 5 에서와 같이 열수 추출물은 $50-200 \mu \mathrm{g} / \mathrm{mL}$ 의 TPC 농도에서 $15.68-26.92 \%$ 의 astringent 효과를 나타내었으나, TPC 농도가 증가함에 따라 감소하는 결과를 나타내었다. $60 \%$ ethanol 추출물의 경우 같은 농도 에서 49.48-86.84\%의 astringent 효과를 나타내었으며, TPC 농도가 증가함에 따라 유의적으로 증가하는 결과를 나타내 었다. Positive control로 사용한 tannic acid는 50-200 $\mu \mathrm{g} / \mathrm{mL}$ 의 농도에서 $41.98-84.53 \%$ 의 astringent 효과를 나타내어 곰취 $60 \%$ ethanol 추출물보다 낮은 효과를 나타내었다. Lee 등(26)은 층꽃나무 ethanol 추출물이 $50-200 \mu \mathrm{gg} / \mathrm{mL}$ 의 농도 에서 $15-50 \%$ 의 astringent 효과를 나타낸다고 보고하였는 데, 위의 결과와 비교하였을 때 곰취 추출물의 astringent 효과가 매우 우수하다고 판단되었다.

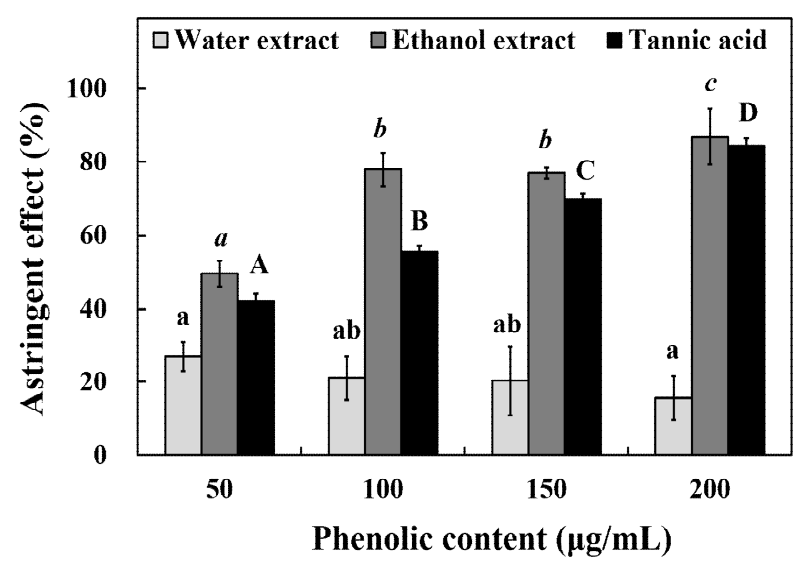

Fig. 5. Astringent effect of water and $60 \%$ ethanol extract from wild Ligularia fischeri.

Values with different alphabet in the column were significantly different among group at $p<0.05$ level by Duncan's multiple range test.

\section{요 약}

본 연구에서는 야생 곰취 추출물의 항산화 효과와 수렴 효과, hyaluronidase와 angiotensin convertin enzyme(ACE) 
의 효소저해 효과를 측정하였다. Total phenolic compounds (TPC)의 추출수율을 알아보기 위하여 다양한 용매를 이용 하여 추출한 결과, 열수 추출물에서 $14.42 \mathrm{GAE} \mathrm{mg} / \mathrm{g}$ 으로 가장 높은 추출수율을 나타내었다. 곰취 추출물의 항산화 효과를 측정하기 위하여 50-200 $\mathrm{\mu g} / \mathrm{mL}$ 의 농도에서 ABTS radical 소거능을 측정해본 결과, 열수 추출물과 $60 \%$ ethanol 추출물에서 각각 $98.64-99.84 \%, 95.14-98.96 \%$ 의 radical 소 거능을 나타내었다. $\mathrm{PF}$ 를 측정해본 결과, 열수 추출물에서 는 0.59-1.02 PF를 나타내었고, $60 \%$ ethanol 추출물에서는 0.30-0.74 PF를 나타내었다. 곰취 추출물의 효소저해를 통 한 생리활성 효과를 알아보기 위하여 hyaluronidase 저해 효과를 측정해본 결과, 열수 추출물은 $50-200 \mu \mathrm{g} / \mathrm{mL}$ 의 TPC 농도에서 4.66-35.00\%의 저해 효과를 나타내었으나 ethanol 추출물은 저해효과를 나타내지 않았다. Angiotensin converting enzyme(ACE) 저해 효과를 측정해본 결과, 열수 추출물과 $60 \%$ ethanol 추출물에서 각각 $0-64.24 \%$ 와 46.12$69.64 \%$ 의 $\mathrm{ACE}$ 저해 효과를 나타내었다. Astringent 효과를 측정해본 결과, 열수 추출물은 $50-200 \mathrm{\mu g} / \mathrm{mL}$ 의 TPC 농도에 서 15.68-26.92\%를, $60 \%$ ethanol 추출물의 경우 같은 농도에 서 49.48-86.84\%의 astringent 효과를 나타내어 피부미용 측면에서는 모공 축소현상으로 활용이 가능할 것으로 판단 되었다.

이상의 결과에 따라 야생 곰취 추출물은 염증 유발에 관여하는 hyaluronidase 및 혈압 상승에 영향을 주는 angiotensin converting enzyme의 억제효과가 우수하며, $\mathrm{ABTS}$ 와 PF 등의 항산화 활성이 우수함이 밝혀져, 이러한 생리활성을 활용한 건강기능성 식품의 원료로 이용이 가능 할 것으로 판단되었다.

\section{References}

1. Chang SK, Kim JH, Oh HS (2008) The development of functional cold buckwheat noodles using biological activities of hot water extracts of Ligularia fischeri and Angelica gigas Nakai. Korean J Food Cult, 23, 479-488

2. Ham SS, Lee SY, Oh DH, Jung SW, Kim SH, Chung CK, Kang IJ (1998) Antimutagenic and antigenotoxic effects of Ligularia fischeri extracts. J Korean Soc Food Sci Nutr, 27, 745-750

3. Cho SD, Kim GH (2005) Food product development and quality characteristics of Ligularia fischeri for food resources. Korean J Food Preserv, 12, 43-47

4. Na Y, Kim JH, Sim HS, Lee BC, Pyo HB (2006) Effect of antioxidation and inihbition of matrix metalloproteinase-1 from Ligularia fischeri. J Soc Cosmet Sci Kor, 32, 129-134
5. Ham SS, Lee SY, Oh DH, Jung SW, Kim SH, Chung CK, Kang IJ (1998) Cytotoxicity of Ligularia fischeri extracts. J Korean Soc Food Sci Nutr, 27, 987-992

6. Kwon YJ, Kim KH, Kim HK (2002) Changes of total polyphenol content and antioxidant activity of Ligularia fischeri extracts with different microwave-assisted extraction conditions. Korean J Food Preserv, 9, 332-337

7. Gonzalez R, Ballester I, Lopez-Posadas R, Suarez MD, Zarzuelo A, Martinez-Augustin O, Sanchez De Medina F (2011) Effects of flavonoids and other polyphenols on inflammation. Crit Rev Food Sci Nutr, 51, 331-362

8. Folin O, Denis W (1912) On phosphotungsticphosphomolybdic compounds as color reagents. J Biol Chem, 12, 239-243

9. Fellegrin N, Ke R, Yang M, Rice-Evans C (1998) Screening of dietary carotenoids and carotenoid-rich fruit extracts for antioxidant activities applying 2,2'-azinobis (3-ethylenebenzothiazoline-6-sulfonic acid radical cation decolorization assay. Methods Enzymol, 299, 379-389

10. Andarwulan N, Shetty K (1999) Phenolic content in differentiated tissue cultures of untransformed and Agrobacterium-transformed roots of anise (Pimpinella anisum L.). J Agric Food Chem, 47, 1776-1780

11. Dorfman A, OTT ML (1948) A turbidimetric method for the assay of hyaluronidase. J Biol Chem, 172, 367-375

12. Cushman DW, Cheung HS (1971) Spectrophotometric assay and properties of the angiotensin-converting enzyme of rabbit lung. Biochem Pharmacol, 20, 1637-1648

13. Lee JT, Jeong YS, An BJ (2002) Physiological activity of Salicornia herbacea and its application for cosmetic materials. Korea J Herbol, 17, 51-60

14. Vogt T (2010) Phenylpropanoid biosynthesis. Molecular Plant, 3, 2-20

15. Pandey KB, Rizvi SI (2009) Plant polyphenols as dietary antioxidants in human health and disease. Oxid Med Cell Longevity, 2, 270-278

16. Han SR, Noh MY, Lee JH, Oh TJ (2015) Evaluation of antioxidant and antimicrobial activities of solvent extracts from Coriolus versicolor. J Korean Soc Food Sci Nutr, 44, 1793-1798

17. Song WY, Byeon SJ, Choi JH (2015) Anti-oxidative and anti-inflammatory activities of Sasa borealis extracts. J Argric Life Sci, 49, 145-154

18. Toyosaki $\mathrm{T}$ (2002) Antioxidant effect of $\beta$-carotene on lipid peroxidation and synergism with tocopherol in an emulsified linoleic acid model system. Int J Food Sci 
Nutr, 53, 419-423

19. Jackson DG (2009) Immunological functions of hyaluronan and its receptors in the lymphatics. Immunol Rev, 230, 216-231

20. Fronza M, Caetano GF, Leite MN, Bitencourt CS, Paula-Silva FW, Andrade TA, Frade MAC, Merfort I, Faccioli LH (2014) Hyaluronidase modulates inflammatory response and accelerates the cutaneous wound healing. PLoS One, 9, e112297

21. An TEB, Kim DC (2016) In vitro cytotoxicity, skin regeneration, anti-wrinkle, whitening and in vivo skin moisturizing effects of Oncheongeum. J Korean Obstet Gynecol, 29, 14-34

22. Jo YB, Lee JH (2016) A study on the effect of the Dendropanax mobifera extract on anti-hypertensive. J Korea Acad-Ind Coop Soc, 17, 708-715
23. Kang SM, Kim SJ, Nam SH (2017) Inhibitory effect of cell differentiation against 3T3-L1 pre-adipocytes and angiotensin converting enzyme (ACE) activity of ice plant (Mesembryanthemum crystallinum). J Korean Soc Food Sci Nutr, 46, 1012-1017

24. Kwon YR, Youn KS (2014) Antioxidant activity and physiological properties of Moringa (Moringa oleifera Lam.) leaves extracts with different solvents. Korean J Food Preserv, 21, 831-837

25. Lesschaeve I, Noble AC (2005) Polyphenols: factors influencing their sensory properties and their effects on food and beverage preferences. Am J Clin Nutr, 81, 330S-335S

26. Lee JE, Lee EH, Kim BO, Cho YJ (2017) Biological activities of extracts from Caryopteris incana Miq. J Appl Biol Chem, 60, 61-68 